\title{
Determining shopping malls customers' satisfaction and loyalty
}

\author{
Makgopa, SS \\ University of South Africa, South Africa
}

\section{Keywords}

shopping mall, customers satisfaction, customer loyalty, quantitative research, descriptive analysis

\begin{abstract}
The shopping mall retailers are operating in a highly competitive retail environment which requires effective management in order to satisfy the customers and achieve customers' loyalty. The primary purpose of this paper was to determine the satisfaction and loyalty among shopping mall customers about the shopping malls. Secondly, this study aimed to determine whether statistically significant differences exist between the means of the shopping mall customers considering their age groups and gender. A quantitative research approach was followed to achieve research objectives. Self-administered questionnaires were used during data collection at the Kolonnade Shopping Centre in Gauteng Province, South Africa. Descriptive statistics and parametric tests, in the form of independent samples t-tests and One-way ANOVAs, were used to determine significant differences between different age groups. SPSS Version 23 software was used for analysing quantitative data. Internal consistency reliability of the measurement scales measuring shopping mall customers' shopping motives were assessed by calculating Cronbach's alpha values. The results of the study uncovered that the satisfaction level amongst the shopping mall customers tend to be high. The results further provided an important understanding of the relationship of demographics (age and gender) on customers' satisfaction levels and loyalty at the shopping mall. This study contributes to the current literature and provides valuable information to retailers and shopping mall developers in general, with regard to marketing communications and marketing strategies that aim to attract shopping mall customers. Suggestions for future research are provided.
\end{abstract}

Corresponding author: Makgopa S S

Email address for corresponding author: makgoss@unisa.ac.za

First submission received: $18^{\text {th }}$ December 2017

Revised submission received: $16^{\text {th }}$ March 2018

Accepted: $3^{\text {rd }}$ April 2018

\section{Introduction}

The shopping is an important activity of consumers' lives and it is continually changing, making the investigation and understanding of this field important in order to create a pleasant shopping experience and achieve customers' satisfaction. The study of consumer behaviour is not recent. Since the 1950s, the rational and emotional contexts of consumption have been studied. Several shopping classifications were proposed, shaping a number of motives into two forms, namely, hedonic and utilitarian shopping motivations. Shopping motivations have been researched in consumer shopping behaviour over the past decades (Wagner \& Rudolph, 2010). Shopping mall customers visit shopping malls not only to search for products, but they also view these shopping mall visits as an entertainment activity that provides fun and pleasure (Kim, Lee \& Kim, 2011). Shopping mall customers tend to engage in various activities when visiting shopping malls (Farrag, El Sayed and Belk, 2010). According to Kim, Lee and Suh (2015) today's customers tend to purchase products while spending time in a shopping mall, which includes a combination of shopping and culture, rather than just going to a mall for the sole purpose of purchasing goods, and this has already become a lifestyle. Hunneman, Verhoef and Sloot (2017) added that consumers tend to assess store attributes differently depending on the type of shopping trip. In this paper the focus is on customer satisfaction and loyalty at a shopping mall from South African context due to limited studies on the topic.

The next section outlines the research purpose of this paper in detail. 


\section{Research purpose}

The competition in the retail environment requires shopping mall managers to find better ways to attract shopping mall customers. To achieve this goal, it is necessary to determine the shopping malls customers' satisfaction level and their level of loyalty towards the mall. The study focused at one of regional shopping malls located in South Africa, in the City of Tshwane, namely, Kolonnade Shopping Centre.

The next section presents theoretical background and literature review on previous studies on shopping malls.

\section{Theoretical background and literature review}

This section focuses on the previous literature on shopping malls starting with the background on shopping mall, particularly, the definition of shopping mall, and followed by different shopping motivations that motivate shopping mall customers to visit shopping malls are also revised. Secondly, previous studies that investigated significant differences between demographic characteristics of shopping mall customers and hedonic and utilitarian motivation are reviewed. Finally, previous studies that determined the shopping mall customers' satisfaction and loyalty levels towards shopping malls and the importance in shaping shopping mall customers' behaviour are also reviewed.

\subsection{The definition of shopping malls}

Shopping malls are characterised as venues that enable a comfortable shopping experience and have turned into social centres and recreational facilities for various activities (Telci, 2013). At the beginning of their life cycle, shopping malls were primarily economic entities that provide shopping mall customers with a wide selection of stores and merchandise at a single location. Shopping malls have adapted to new designs and tenant varieties to meet the changes in consumers' needs, desires, values, and lifestyles. This view on shopping malls is also supported by Farrag et al. (2010) that shopping malls have shifted from involving just a traditional shopping activity to retail-entertainment complexes and community centres for social and recreational activities. In addition, according to Farrag et al. (2010) shopping mall customers visit these shopping malls for various motivations.

There are different types of shopping malls, namely, convenience shopping mall, neighbourhood shopping mall, community shopping mall, regional shopping mall and super-regional shopping mall. In this study, regional shopping malls were of the primary focus. Regional shopping mall is defined by having two or four major tenant stores in a building and with the floor area between 250,000 to 800,000 square feet. This shopping mall offers business products, domestic appliances, a variety of services and entertaining equipment (Juhari, Ali \& Khair, 2012).

\subsection{Shopping mall customers' shopping motivations}

Shopping mall customers visit shopping malls not only for searching for products, but they also view these visits as an entertainment activity that provides fun and pleasure from the shopping experience (Kim et al., 2011). Shopping mall customers tend to engage in numerous activities when visiting shopping malls (Farrag et al., 2010). This is further supported by Gilboa (2009) who identified activities and grouped them according to the following categories:

\subsubsection{Consumption activities by shopping mall customers}

Consumption activities are activities that involve visiting coffee-shops/restaurants, gaining new knowledge regarding new products and trends, and window shopping. Farrag et al. (2010) indicated that window shopping involves a situation where a shopping mall customer browses or goes through window displays to feel part of shopping mall culture and environment. This browsing on window displays allows shopping mall customers to keep track of fashions and keep themselves informed of the latest changes in the retail market. Shopping mall customers also visit restaurants and coffee shops at the shopping mall just to have a cup of coffee or for lunch. In addition, family members can also go to these restaurants together for family bonding (Farrag et al., 2010). Kuruvilla and Joshi (2010) added that within a shopping mall, shopping mall customers may be categorised into groups that differ in their shopping reasons such as browsing, purchasing clothing, shoes, accessories and gifts.

Kuruvilla and Joshi (2010) pointed that different shopping mall customers patronise the shopping mall and can have interest in different groups of products. Some may have purposeful shopping activities 
like having refreshments or watching a movie while others may visit the shopping mall for window shopping with no firm objective of buying.

\subsubsection{Participation in shopping mall-initiated activities by shopping mall customers}

According to Gilboa (2009), shopping mall customers can visit shopping malls to participate in mall-initiated activities as part of entertainment. These entertainment activities include children's programs and cultural events. This is backed by Farrag et al. (2010) indicating that shopping mall customers can visit shopping malls to attend fashion shows. In addition, when family members visit these shopping malls, it can present children with an opportunity to play around at various entertainment arenas.

\subsubsection{The use of the shopping mall facilities by shopping mall customers}

Shopping mall customers can visit the shopping mall to access primary services offered by the shopping mall, such as visiting the gym, post office and banks (Gilboa, 2009).

\subsubsection{Social activities}

Social activities are activities that involve human interaction and include strolling; social meetings, sitting in public places, speaking with strangers and watching others shop (Gilboa, 2009). Shopping mall customers indulge in consumption of experiences and shopping malls have become important meeting places, especially for young people (Kuruvilla \& Joshi, 2010).

\subsubsection{Entertainment}

Shopping mall customers can visit shopping malls to watch movies at movie theatres and watch soccer matches at different restaurants (Gilboa, 2009; Farrag et al., 2010; Kim et al., 2011).

\subsubsection{Shopping mall customers' satisfaction and loyalty}

Juhari et al. (2012) pointed that an evaluation of the shopping mall needs to be carried out that includes the management of shopping mall's service scape, physical environment, or the service scape of the shopping mall. This service scape dimensions can help to identify a specific item or area that need. The argument of this paper is that a comprehensive, attractive and well-functioning shopping mall, with a variety of facilities and services is necessary to satisfy the customer. Satisfaction is a degree of meeting the needs at the end of a purchase (Puccinelli, Goodstein, Grewal, Price, Raghubir \& Stewart, 2009). Fornell (1992) viewed a customer satisfaction as a function of pre-sale expectations and post-purchase perceived performance. Customers evaluate their purchase decisions during the post-purchase stage to analyse how much the retailer has met their expectations. This comparison of expectation and performance in postpurchase stage determines the satisfaction level of customers.

In a study conducted by Ryu, Han and Jang (2009) it was revealed that the internal and external factors significantly influence customer satisfaction, and customer satisfaction has a significant influence on behavioural intentions. Hui, Zhang and Zheng (2013) analysed the shopping mall facilities service dimensions that affect customer satisfaction. The findings revealed that management and maintenance of communal facilities such as rest rooms, shopping mall's cleanliness, promotional events and security services at the shopping mall influence the overall shopping mall customers' satisfaction. Chebat, Michon, Haj-Salem and Oliveira (2014) determined whether shopping mall design has a direct impact on shopping mall customers' perceptions regarding the shopping mall and an indirect impact on shopping mall customers' hedonic and utilitarian values and satisfaction. The findings revealed that the hedonic values contribute more to shopping mall customers' satisfaction than the utilitarian values. In an article by Chebat, El Hedhli and Sirgy (2009) the main objective was to determine whether the shopping mall customers' loyalty towards a shopping mall is significantly predicted by shopping mall customers' positive awareness of the shopping mall attributes such as the quality of the products and services offered at the shopping mall. According to Chebat et al. (2014) the hedonic shopping value accounts for the emotions associated with customer shopping; the pleasure of shopping, escape from daily routine, being occupied in exciting new products, and spending time in an entertaining way.

In another study, Kotzé, North, Stols, and Venter (2012) investigated gender differences focusing on the sources of shopping enjoyment which includes hedonic shopping motivations. The findings revealed that males and females who enjoy and are satisfied in shopping show positive intentions to 
revisit the shopping mall in the future. In a recent study, El-Adly and Eid (2017) investigated through structural equation modelling (SEM) the relationships between the shopping environment, customer perceived value, customer satisfaction, and customer loyalty in regard to malls in the United Arab Emirates (UAE). The main results of El-Adly and Eid (2017) showed that the shopping mall environment is an antecedent of the customer perceived value of malls and customer satisfaction. To understand the role of satisfaction, Juhari et al. (2012) argue that satisfaction is linked to loyalty, with the customers returning for a particular product or service from the same supplier on a continuous basis. However, Chang and Fang (2012) argue that hedonic value has greater effect on satisfaction and word-of-mouth than utilitarian shopping value. In another study, Babin, Gonzalez and Watts (2007) revealed a contrasting result that utilitarian shopping value has greater effect on customers' satisfaction than hedonic shopping using gift shopping as an example.

3.3 Previous studies on shopping malls

The research suggests that shopping mall customers consider shopping mall attributes when selecting which shopping mall to visit (Jackson, Stoel and Brantley, 2011). Jackson et al. (2011) discovered the way in which shopping mall customers' attitudes towards shopping mall attributes and shopping value derived from a shopping mall visit vary across gender and generational cohorts. The results of survey indicated that there were no differences in hedonic and utilitarian shopping motivations by generational cohort, but generational differences in attitude towards mall hygiene factors, locational convenience and entertainment features tend to exist. In addition, the study discovered that females experience greater levels of hedonic shopping value from visiting the shopping mall and also display more positive attitudes towards shopping mall hygiene factors and entertainment activities in comparison to males' counterparts. There was no difference in utilitarian shopping value and attitude toward locational convenience found between gender differences. El-Adly (2007) investigated the attractiveness factors of United Arab Emirates shopping malls from customers' perspective. The results of this study uncovered that comfort, entertainment, diversity, shopping mall essence, mall convenience, and luxury to be decisive shopping attributes that can be used for segmentation of customers and to satisfy customers' needs.

In another study, Chebat, Sirgy and Grzekowiak (2010) examined shopping mall attributes namely: access to the shopping mall, shopping mall image and store atmosphere that may be used to draw shopping mall customers to shopping malls. The findings of the study confirmed that the shopping mall image has a positive relation to shopping mall attitude, shopping mall patronage, and word-ofmouth communications. Khare (2011) adds that research suggests that convenience as a shopping mall attribute has the largest impact on selecting which shopping mall to visit. The availability of a wide selection of products at the shopping malls can reduce the perceived costs (for example, travel time and effort taken) associated with each shopping trip and ease the shopping task. According to Farrag et al. (2010) shopping mall customers may visit the shopping mall as they consider it to be a safe place because of security measures. Farrag et al. (2010) added that shopping mall customers may perceive a shopping mall to be convenient in terms of having various products and services under one roof.

Kuruvilla and Joshi (2010) point out that shopping mall attributes determine the shopping mall customers' attitude towards shopping malls. According to Kuruvilla and Joshi (2010) shopping mall attributes that influence shopping mall customers' attitude towards shopping malls also include the shopping mall location, variety of stores at shopping mall, availability of parking, shopping mall employee behaviour, price of products and services, quality of products and serves, customer service, promotional activities, shopping mall ambiance, shopping mall facilities, food, refreshments and shopping mall safety. On the other hand, Wagner and Rudolph (2010) examined the moderating impact of the shopping by demonstrating in which way the relationship between activity and demand-specific motivation impacts on consumer shopping behaviour. In a recent study, El-Adly and Eid (2017) determined the customers' perceived value constructs of shopping malls from the Muslim customers' perspective. The results of this study revealed that Muslims customers in malls assess the shopping experience through both cognitive and affective values aligned to the Islamic value of the mall.

Considering the growing numbers of shopping malls, shopping mall customers tend to be more selective in selecting which shopping mall to visit. Shopping mall customers may visit shopping malls 
that appear to be more attractive and with a variety of stores, product and services that are congruent to their needs and preferences. Shopping malls should meet customers' needs in a satisfactory way, in order to achieve or secure return visits behavior (Anselmsson, 2016). Therefore, it is important for shopping mall managers to determine shopping mall customers' satisfaction level and loyalty towards shopping malls such as Kolonnade Shopping Centre in order to improve performance where there is a shortfall and remain competitive.

\section{Contributions of the study}

In reviewing the secondary literature available on shopping malls, it was apparent that studies on consumers' satisfaction and loyalty towards shopping malls is not widely covered in literature. This paper contributes to the literature on the topic by highlighting that there is no significant differences amongst customers' satisfaction and loyalty towards shopping malls in terms of age and gender in a developing economy such as that of South Africa. This paper further benefits shopping mall managers and retailers by providing recommendations on how to best satisfy customers' needs and achieve customers' satisfaction and loyalty at their respective shopping malls. In addition, this paper provides directions for future research.

\section{Research methodology}

The positivist research philosophy was followed in this study. Positivist has a long history in philosophy of science and it arose from the nine-teeth century by Frenchman (1798-1857). Positivist researchers seek rigorous exact measures and objective research, test hypotheses often use experiments, surveys, and statistics (Neuman, 2011:82). This implies that positivist favours quantitative research. The study was quantitative in nature in collecting the primary data to address research objectives. This study was conducted from the $10^{\text {th }}$ of May 2015 and the 30 th of June 2015 among customers at the Kolonnade Shopping Centre in Gauteng Province, South Africa during shopping hours on weekdays and over the weekends. The self-administered questionnaires had to be completed in not more than 20 minutes. No incentives were offered to respondents to participate in the study. The target population in the study consisted of adult shopping mall customers at the Kolonnade Shopping Centre in City of Tshwane, South Africa. One hundred and one adult customers participated in this study. For the purpose of this study, adults were defined as male and female individuals, aged 18 years and older, and of all cultural and racial backgrounds who visited the mentioned shopping mall at least once a month. Customers who visited Kolonnade Shopping Centre served as the respondents in completing a self-administered questionnaire in this study. A non-probability quota sampling plan was used in the study with quotas being filled based on convenience and the personal judgement of researchers at the shopping mall. The first stage of the quota sampling involved compiling the demographic characteristics of respondents in terms of age and gender. The second stage of the quota sampling involves convenience sampling. A convenience sampling method was used in this study as the method is less expensive, less time-consuming, and because there was no available sample frame.

In order to compile a scale of measurement for shopping mall customers' perceptions on their satisfaction and loyalty towards the shopping mall, questionnaire items were adapted from previous study Kursunluoglu (2014) which is frequently used and a reliable measure. A five-point Likert scale was used on the statements to measure shopping mall customers' satisfaction and loyalty levels and the measurement scale is interval in nature. Respondents indicated the extent to which they agreed with the statements on a five-items scale ranging from strongly agree to strongly disagree. The respondents were also requested to provide demographic data regarding age and gender. The draft questionnaire was pretested with twelve respondents using a convenience sample at the shopping mall. It was considered unnecessary to make major changes on the draft questionnaire except for minor adaptations on wording as respondents reported no problems with the questionnaire. Descriptive statistics and parametric tests were used in this study to analyse the primary data on demographic variables of shopping mall customers, and shopping mall customers' perception on their satisfaction and loyalty towards the mall. The Statistical Package for Social Science (SPSS version 23) was used to automatically capture and analyse data on handheld devices. An Independent samples t-test was conducted to discover whether a statistically significant difference exists between the means of shopping mall customers' groups in terms 
of their age and gender with respect to their satisfaction and loyalty towards the shopping mall they visited. A One-way ANOVA was conducted to determine whether statistically significant differences exist between the means of the different age groups with respect to their utilitarian and hedonic shopping motives. In addition, the reliability of the measurement scales was assessed by measuring internal consistency using Cronbach's alpha values. Cronbach alpha is used to measure the internal consistency reliability, which is the average of all possible split-half coefficients resulting from different splittings of scale items (Malhotra, 2010). The validity of the measurement scales was assessed looking at face or content validity and used scales that proved to be previously valid.

In line with the overall research objectives of the study, table 1 below depicts the variables (age, gender, customers' satisfaction and loyalty analysed during the data analysis.

Table 1: Variables used in the data analysis

\begin{tabular}{|l|l|l|}
\hline Variable name & Level of measurement & Univariate descriptive statistics \\
\hline Age & Nominal scale & Percentages, mode \\
\hline Gender & Nominal scale & Percentages, mode \\
\hline Customer satisfaction & Interval scale & Range, mean, standard deviation \\
\hline Loyalty & Interval scale & Range, mean, standard deviation \\
\hline
\end{tabular}

The next section presents the results of this study.

\section{Results}

This section presents the results of the current study starting with demographic profiles followed by results on shopping mall customers' satisfaction and loyalty.

6.1 Demographic profile of respondents in the quantitative phase

This section presents the demographic profiles of respondents in terms of gender and age group.

Table 2: Demographic profile of respondents

\begin{tabular}{|l|l|l|}
\hline Demographic variable & Kolonnade Shopping Centre \\
\hline Gender & $\mathbf{N}$ & $\mathbf{\%}$ \\
\hline Male & 51 & 50.5 \\
\hline Female & 50 & 49.5 \\
\hline Total & $\mathbf{1 0 1}$ & $\mathbf{1 0 0}$ \\
\hline Age group & $\mathbf{N}$ & $\mathbf{\%}$ \\
\hline 18 to 24 years & 11 & 10.9 \\
\hline 25 to 34 years & 31 & 30.7 \\
\hline 35 to 49 years & 30 & 29.7 \\
\hline 50 years and older & 29 & 28.7 \\
\hline
\end{tabular}

Consumers participate in the current study were 51 males and 50 females. The respondents within the age group 18 to 24 years were 10.9\%, respondents with the age group 25 to 34 years were 30.7\%, respondents within the age group 35 to 49 years were $29.7 \%$, and respondents within the age group 50 years and older were $28.7 \%$.

6.2 Customers satisfaction and loyalty

This section provides the findings regarding the respondents' satisfaction and loyalty levels towards the Kolonnade Shopping Centre. Table 3 depicts the mean scores and standard deviations to question statement used to determine respondents' satisfaction and loyalty levels towards the Kolonnade Shopping Centre.

Table 3: Shopper satisfaction and loyalty

\begin{tabular}{|l|l|l|}
\hline \multirow{2}{*}{ Satisfaction } & \multicolumn{2}{|c|}{ Kolonnade } \\
Centre & SDopping \\
\cline { 2 - 3 } & M & 0.34 \\
\hline I am satisfied with what this shopping mall/centre offers & 4.31 & 0.986 \\
\hline The offerings at this shopping mall/centre are better than I expected & 3.64 & 0.939 \\
\hline The offerings of this shopping mall/centre are ideal & 3.67 & \\
\hline
\end{tabular}

www.jbrmr.com A Journal of the Academy of Business and Retail Management (ABRM) 


\begin{tabular}{|l|l|l|}
\hline Satisfaction & $\begin{array}{l}\text { Kolonnade Shopping } \\
\text { Centre }\end{array}$ \\
\hline \multirow{2}{*}{ Loyalty } & $\begin{array}{l}\text { Kolonnade Shopping } \\
\text { Centre }\end{array}$ \\
\cline { 2 - 3 } & M & SD \\
\hline I do most of my shopping at this shopping mall/centre & 3.77 & 1.028 \\
\hline I recommend this shopping mall/centre to others & 3.92 & 1.036 \\
\hline I will shop at this shopping mall/centre in future & 4.38 & 0.823 \\
\hline
\end{tabular}

Table 3 indicates the satisfaction and loyalty levels respondents have towards Kolonnade Shopping Centre. Respondents at Kolonnade Shopping Centre agree the most with the statement "I will shop at this shopping mall/centre in future" (mean=4.38) and followed by "I am satisfied with what this shopping mall/centre offers" (mean $=4.31$ ), and agree the least with the statement "The offerings at this shopping mall/centre are better than expected" (mean $=3.64)$. For Kolonnade Shopping Centre, the standard deviation (SD) for the three statements for shopping mall satisfaction range between 0.34 and 0.986 , and the standard deviation (SD) for the three statements for shopping mall loyalty range between 0.823 and 1.036 .

\subsubsection{Satisfaction}

Table 4 provides the results for the significant testing undertaken to reveal statistically significant differences between groups based on gender, age, and shopping mall satisfaction.

Table 4: Significant differences between groups with respect to satisfaction

\begin{tabular}{|l|l|l|l|}
\hline Variable & Category & Mean & p-value \\
\hline \multirow{3}{*}{ Gender } & Male & 3.80 & \multirow{2}{*}{0.351} \\
\cline { 2 - 3 } & Female & 3.86 & \\
\hline \multirow{4}{*}{ Age } & 18 to 24 years & 3.95 & \multirow{3}{*}{0.351} \\
\cline { 2 - 3 } & 25 to 34 years & 3.78 & \\
\cline { 2 - 3 } & 35 to 49 years & 3.79 & 3.86 \\
\cline { 2 - 3 } & 50 years and older & & \\
\hline
\end{tabular}

*indicates statistically significant difference between the means of the groups ( $\mathrm{p}$-value equal or less than $0.05)$

Satisfaction and gender: An Independent samples t-test was conducted to discover whether a statistically significant difference exists between the means of males (3.80) and females (3.86) with respect to their levels of satisfaction with the shopping mall they were visiting. A p-value of 0.351 signifies that a statistically significant difference between the means of males and females with respect to satisfaction is not evident.

Satisfaction and age: A One-way ANOVA was conducted to determine whether statistically significant differences exist between the means of the different age groups with respect to their levels of satisfaction with the shopping mall they were visiting. A p-value of 0.351 point out that a statistically significant difference between the means of the different age groups with respect to satisfaction is not evident.

\subsubsection{Loyalty}

Table 5 provides the results for the significant testing undertaken to uncover statistically significant difference between groups based upon gender, age, and shopping mall loyalty.

Table 5: Significant differences between groups with respect to loyalty

\begin{tabular}{|l|l|l|l|}
\hline Variable & Category & Mean & p-value \\
\hline \multirow{4}{*}{ Gender } & Male & 3.92 & \multirow{2}{*}{0.118} \\
\cline { 2 - 3 } & Female & 4.03 & \\
\hline \multirow{4}{*}{ Age } & 18 to 24 years & 3.94 & \\
\cline { 2 - 3 } & 25 to 34 years & 3.97 & \\
\cline { 2 - 3 } & 35 to 49 years & 3.91 & \\
\cline { 2 - 3 } & 50 years and older & 4.08 & \\
\hline
\end{tabular}


*indicates statistically significant difference between the means of the groups ( $\mathrm{p}$-value equal or less than $0.05)$

Loyalty and gender: An Independent samples t-test was conducted to discover whether a statistically significant difference exists between the means of males (3.92) and females (4.03) with respect to their loyalty with the shopping mall they were visiting. A p-value of 0.118 signifies that a statistically significant difference between the means of males and females with respect to loyalty is not evident.

Loyalty and age: A One-way ANOVA was conducted to determine whether statistically significant differences exist between the means of the different age groups with respect to their loyalty with the shopping mall they were visiting. A p-value of 0.256 point out that a statistically significant difference between the means of the different age groups with respect to loyalty is not evident.

\subsubsection{Validity and reliability}

This sub section shows that the internal consistency reliability of the measurement scales measuring customers' satisfaction and loyalty which were assessed by calculating Cronbach's alpha values. Cronbach's alpha value of 0.6 or higher indicates that the measurement scale is reliable (Malhotra, 2007). Table 6 below briefly presents the Cronbach's alpha values for each variable measured. All Cronbach's alpha values exceeding 0.6 indicate internal consistency reliability and validity for all measurement scales.

Table 6: Internal consistency reliability of measurement scales

\begin{tabular}{|l|l|l|}
\hline Measurement scale & Number of items & Cronbach's alpha value \\
\hline Customers' satisfaction & 3 & 0.780 \\
\hline Loyalty & 3 & 0.715 \\
\hline
\end{tabular}

The next section provides the conclusions and discussions derived from the results of this study.

\section{Conclusions and discussions}

The purpose of this study was to determine the shopping malls customers' satisfaction level and their level of loyalty towards the shopping mall, particularly, Kolonnade Shopping Centre. The results of this study uncovered that there is no significant difference between loyalty and gender, loyalty and age. The findings of the current study agree with the findings of the study by Kotze et al. (2012:421) in that males and females who enjoy shopping show positive intentions to revisit the shopping mall in the future. There is no significant difference between satisfaction and gender, between satisfaction and age. This finding disputes the findings by Farrag et al. (2010:112) and Kotze et al. (2012:420) in that females carry out most shopping for the benefit of other household members and that females tend to enjoy shopping at shopping malls than male counterparts. These results imply the context and the economic level of the country can serve as a decisive factor in determining the significant differences amongst consumers with regard to their shopping behaviour, satisfaction and loyalty levels at shopping malls.

The next two sections outline recommendations to stakeholders and future research implications of the current study.

\section{Implications}

The shopping mall managers and retail managers could develop marketing strategies that cater for different types of customers considering their demographic characteristics particularly age and gender. Shopping mall retailers can attract customers by using promotional activities that emphasise new fashion trends and technological innovations in order to cate for needs of idea shoppers. In order to cater for adventurous needs of shopping mall customers and ensures customer satisfaction, shopping mall managers could develop promotional programmes that would make customers perceive the shopping malls as unique and stimulating. In order to achieve customer loyalty, the mall developers could develop the malls with an environment that fosters social activities with unique features that can serve as differentiated attributes from other competing malls in the area. Therefore, the paper's significance and implications can be found in the explanation that the shopping mall attributes has an effect on the customers' loyalty towards the shopping mall visited through the satisfaction derived from the shopping experience at shopping mall. 


\section{Limitations and future research}

The study was conducted in Gauteng province, South Africa at one shopping centre based in the City of Tshwane, Pretoria, and further study should include large number of shopping malls in Gauteng province. In addition, a future study including other shopping malls in other provinces of South Africa is recommended. Ethnographic research is recommended to gain a deeper understanding of stores visited by these shopping mall customers. Focusing more on the store as a unit of analysis could potentially enhance the findings of this study. Furthermore, research on the specific days or times of the month could also provide deeper understanding to the main reasons of visiting the shopping malls and why shopping malls are mainly crowded on specific occasions such as Christmas and Easter. Lastly, future research could investigate the role of customers' personality, religious belief and other demographic variables such as education level and income level on customers' satisfaction and loyalty at the shopping malls in other parts of the world.

The last two sections provide acknowledgement and reference list of sources consulted in writing this paper.

Acknowledgements

The assistance with data analysis by Professor Danie Petzer is hereby acknowledged.

\section{References}

Anselmsson, J. (2016). Effects of shopping centre re-investments and improvements on sales and visit growth. Journal of Retailing and Consumer Services, 32 (1):139-150.

Babin, B.J., Gonzalez, C. and Watts, C., 2007. Does Santa have a great job? Gift shopping value and satisfaction. Psychology \& Marketing, 24(10), 895-917.

Chang, H.H. and Fang, W., 2012. The effects of shopping value on retail outcomes: a comparison between department stores and hypermarkets. The Service Industries Journal, 32(14), 2249-2263.

Chebat, J. C., El Hedhli, K. and Sirgy, M. J. (2009). How does shopper-based mall equity generate mall loyalty? A conceptual model and empirical evidence. Journal of Retailing and Consumer Services, 16(1):50-60.

Chebat, J. C., Michon, R., Haj-Salem, N. and Oliveira, S. (2014). The effects of mall renovation on shopping values, satisfaction and spending behaviour. Journal of Retailing and Consumer Services, 21(4):610-618.

Chebat, J.C., Sirgy, M.J. and Grzeskowiak, S. (2010). How can shopping mall management best capture mall image? Journal of Business Research, 63:735-740.

El-Adly, M. I. (2007). Shopping malls attractiveness: a segmentation approach. International Journal of Retail and Distribution Management, 35(11):936-950.

El-Adly, M. I. and Eid, R. (2017). Dimensions of the perceived value of malls: Muslim shoppers' perspective. International Journal of Retail and Distribution Management, 45(1):40-56.

Farrag, D. A., El Sayed, I. M. and Belk, R. W. (2010). Mall shopping motives and activities: a multimethod approach. Journal of International Consumer Marketing, 22(2):95-115.

Fornell, C. (1992). A national customer satisfaction barometer: the Swedish experience. Journal of Marketing, 56(1):6-21.

Gilboa, S. 2009. A segmentation study of Israeli mall customers. Journal of Retailing and Consumer Services, 16(2):135-144.

Hui, E. C., Zhang, P. H. and Zheng, X. (2013). Facilities management service and customer satisfaction in shopping mall sector. Facilities, 31(5/6):194-207.

Hunneman, A., Verhoef, P. C. and Sloot, L. M. (2017). The moderating role of shopping trip type in store satisfaction formation. Journal of Business Research, 78:133-142.

Jackson, V., Stoel, L. and Brantley, A. (2011). Mall attributes and shopping value: differences by gender and generational cohort. Journal of Retailing and Consumer Services, 18:1-9.

Juhari, N.H., Ali, H.M. and Khair, N. (2012). The shopping mall servicescape affects customer satisfaction. 3rd International Conference on Business and Economic Research (3rd ICBER 2012) Proceeding, Indonesia, (1213):617-632.

Khare, A. (2011). Mall shopping behaviour of Indian small town consumers. Journal of retailing and consumer services, 18(1):110-118.

Kim, Y. H., Lee, M. Y. and Kim, Y. K. (2011). A new shopper typology: Utilitarian and hedonic perspectives. Journal of Global Academy of Marketing, 21(2):102-113.

Kim, J. W., Lee, F. and Suh, Y. G. (2015). Satisfaction and loyalty from shopping mall experience and brand personality. Services Marketing Quarterly, 36(1):62-76.

Kotzé, T., North, E., Stols, M., \& Venter, L. (2012). Gender differences in sources of shopping enjoyment. International Journal of Consumer Studies, 36(4):416-424. 
Kursunluoglu, E. (2014). Shopping mall customer service: creating customer satisfaction and loyalty. Marketing Intelligence and Planning, 32(4):528-548.

Kuruvilla, S. J. and Joshi, N. (2010). Influence of demographics, psychographics, shopping orientation, mall shopping attitude and purchase patterns on mall patronage in India. Journal of Retailing and Consumer Services, 17(4):259269.

Malhotra, N.K. (2010). Marketing research: an applied orientation. 6th Global Edition. Upper Saddle River, NJ: Pearson.

Neuman, W.L. (2011). Social research Methods: Qualitative and Quantitative Approaches. 7th Edition. Pearson, South Africa.

Puccinelli, N.M., Goodstein, R.C., Grewal, D., Price, R., Raghubir, P. and Stewart, D. (2009). Customer experience management in retailing: understanding the buying process. Journal of Retailing, 85(1):15-30.

Ryu, K., Han, H. and Jang, S.S. (2009). Relationships among hedonic and utilitarian values, satisfaction and behavioural intentions in the fast-casual restaurant industry. International Journal of Contemporary Hospitality Management, 22(3):416-432.

Telci, E. E. (2013.) High shopping mall patronage: is there a dark side? Quality and Quantity, 47(5):2517-2528.

Wagner, T. \& Rudolph, T. (2010). Towards a hierarchical theory of shopping motivation. Journal of Retailing and Consumer Services, 17(5):415-429. 